\title{
Çevrecilik Yönelimli Pazarlama Stratejisi Kararları: Türkiye ve Dünya Genelinde Uygulama Örnekleri*
}

\section{The Environmental Oriented Marketing Strategy Decisions: Practices in Turkey and Worldwide}

\author{
Arzu Kılıç a,*** \\ ${ }^{a}$ Dr. Öğr. Üyesi, Ardahan Üniversitesi, İktisadi ve İdari Bilimler Fakültesi, 75000, Ardahan/Türkiye \\ ORCID: 0000-0001-7020-0727
}

\section{MAKALE BİLGİSI}

\section{Makale Geçmiși:}

Başvuru tarihi: 16 Mayıs 2018

Düzeltme tarihi: 05 Ağustos 2018

Kabul tarihi: 30 Eylül 2018

\section{Anahtar Kelimeler:}

Çevre

Çevrecilik Yönelimli Pazarlama

Pazarlama Stratejisi

\section{ÖZ}

Yaşadığımız çevrenin görsel bir güzellik olmaktan öte, ekonomik anlamlarda ifade edilmeye başlanması ve yaşanılan çevre sorunlarının yerel boyutlardan çıkıp küresel boyutlarda etkisini hissettirmesi ile çevre koruma çalışmaları hız kazanmıştır. Günde milyonlarca ton çöp üreten ülkeler, sahip oldukları bu atıkları nasıl değerlendireceklerini veya nasıl kurtulabileceklerini düşünmeye başlamıştır. Çevresel sorunların artmasıyla ekonomik hammaddelerin nasıl ve nereden temin edileceği, var olanı yok etmeden yerine yenisinin nasıl konulacağının araştırılması, bütün kesimler için önemli bir konu haline gelmiştir. İşletmeler bu kapsamda çevreye daha az zarar veren ürün üretmeye ve genel üretim yapılarında değişiklikler yapmaya başlamışlardır. Bu gelişmeler ürünlerin pazarlanma stratejilerini de etkilemiştir. Bu çalışmada çevre, çevrecilik ve çevrecilik yönelimli pazarlama kavramları incelenmiştir. Temel olarak başarılı bir çevreci yönelimli pazarlama stratejisi geliştirmek için izlenmesi geren temel adımlar ele alınmıştır. Ayrıca günümüzde bu konuda başarılı çalışmalar gerçekleştiren ulusal ve küresel şirketlerin uygulamalarından örnekler verilmiştir.

\section{A B S T R A C T}

Environmental conservation work has gained momentum not only because of the visual beauty of the environment we are in, but also because it is beginning to be expressed in economic terms and because of environmental impacts on global scale. Countries that produce millions of tons of waste a day have started to think about how to treat these wastes or how to get rid of them. Investigating how and where to obtain economic raw materials with the increase of environmental problems, and how to put new ones instead of destroying existing ones has become an important issue for all sectors. In this context, enterprises have begun to produce less harmful products and to make changes in general production structures. These developments have also influenced strategies for marketing of products.In this study, environmental, environmental and environmental oriented marketing concepts were examined. Essentially, the basic steps that should be followed to develop a successful environmental-oriented marketing strategy were examined. In addition, examples of the practices of national and global companies that have been successful in this field are given.

\section{Giriş}

Çevre sorunları, küreselleşmenin etkisiyle yerel düzeyde kalmayarak dünya geneline yayılmıştır. Birçok ülkede faaliyet gösteren çevreci sivil toplum örgütleri, hükümetler ve insanlar bu sorunun çözüm yollarını aramak için bir araya gelmişlerdir. Yapılan birçok toplantıda sorunun çözümü için her kesime düşen görevler ve sorumluluk alanları belirlenmeye çalışılmıştır.
Bilinçlenen tüketiciler, çevre sorunlarına karşı her geçen gün daha hassas davranış biçimleri sergilemektedirler. $\mathrm{Bu}$ davranış biçimleri işletmeler üzerinde bir baskı gücü oluşturmaktadır. Aynı zamanda toplumu bilinçlendirmeyi amaç edinen çevreci örgütler, hükümetler, uluslararası kuruluşlar, işletmeleri çevreye karşı daha sorumlu davranmaya yönlendirmek için faaliyete başlamışlardır.

\footnotetext{
* Bu çalışma, 1999 yılında Mustafa Kemal Üniversitesi Sosyal Bilimler Enstitüsü tarafından kabul edilen "Çevrecilik Yönelimli Pazarlama Stratejisi Kararları ve Bir Sektör Uygulaması" adlı Yüksek Lisans tezinden türetilmiştir.

** Sorumlu yazar/Corresponding author.

e-posta: arzukilic@ardahan.edu.tr
} 
Bütün bu gelişmelerin sonucunda işletmeler, sosyal sorumluluk bilinci ile birlikte toplumun değişik kesimlerinden gelen tepkilere cevap olarak çevreyi korumayı ve gözetmeyi amaç edinen çalışmaları örgüt kültürleri içine almaya çalışmışlardır. Bu çalışmada çevre, çevrecilik ve çevrecilik yönelimli pazarlama kavramları incelenmiştir. Başarılı bir çevrecilik yönelimli pazarlama stratejisi gerçekleştirilmesi için alınması gereken kararların neler olması gerektiği, çevrecilik yönelimli pazarlamanın işletmelerde uygulanması için hangi aşamaların yerine getirilmesi gerektiği, pazarlama çalışmalarının uygulanacağı hedef pazar belirleme çalışmaları, pazarlama karması elemanlarında bu uygulamanın hangi boyutlarda yapılabileceği üzerinde durulmuştur. Ayrıca Türkiye ve Dünya genelinde işletmeler tarafından yapılan uygulama örneklerine yer verilmiştir.

\section{Kavramsal Çerçeve}

2.1. Çevre, Çevrecilik ve Çevrecilik Yönelimli Pazarlama Kavramlarının Tanımlanması

İnsanoğlu yaşamını sürdürebilmek için yüzyıllar boyunca birçok ihtiyaçla karșı karşıya kalmış ve bu ihtiyaçlarını her zaman karşılayacağı bir kaynağa sahip olmuştur. Ancak bu kaynak, yine kendisi tarafından bilinçsizce kullanılarak yok olma sınırına getirilmiştir. İlk çağlardan sanayileşme sürecine kadar olan dönemde doğal kaynaklar bireysel ihtiyaçların karşılanması için kullanılırken, sanayi devriminden bu yana kaynaklar uluslararası ihtiyaçların karşılanması için kullanılmıştır. "Hava ve su gibi doğal kaynaklar ekonomik açıdan "serbest mal" durumuna gelmiştir” (Kışlalıŏ̆lu ve Berkeş, 1989: 17).

Çevre kavramı çok geniş anlamlar içermektedir. "Çevre, genel olarak insanın bütün sosyal, biyolojik, fiziksel ve kimyasal uğraşlarını içinde sürdürdügü bir ortamdır" (Çevikbaş, 1991: 9). "Çevre, belirli bir anda canlı ve insan faaliyeti üzerinde doğrudan ve dolayll etki eden veya yapan sosyal faktörlerle biyolojik, fiziksel ve kimyasal koşulların bütünüdür” ( Kışlalığlu ve Berkeş, 1989: 12). "Çevre, dar anlamda tabii ortam şartlarının bir toplamı, geniş anlamda ise, bulunulan sosyal şartların bir toplamı olarak düşünülür" (Bilge vd., 1985: 38). Bütün bu tanımları özetlersek, çalışmamızda söz konusu olan çevre, yaşamın gelişmesini etkileyen sosyal, kültürel, toplumsal diş etmenlerin bütünlüğü gibi geniş anlamda değil, yalnızca doğal kaynakların bütünlüğünü ifade etmektedir.

“Çevre sorunu oluşumu toplumsal bir olgudur. Toplumsal faaliyetler hammadde çıkartılması, işlenmesi, üretim, dağıtım ve tüketime kadar her safhada kendini gösterir. Dolayısıyla tek bir alana, özellikle tüketicilerin günlük kullanım ve atık alanına sıkıştırılınca oluşumun önemli kısımları ihmal edilmiş olur" ( Erdoğan ve Ejder, 1997: 82). Çevre sorunlarının gün geçtikçe çeşitlenerek artması ile birlikte bu konuda hassas davranan ve konunun önemini gerçekçi boyutları ile düşünen, topluma düşündürmeyi amaç edinen "çevrecilik" hareketi ortaya çıkmıştır ve zaman geçtikçe hükümetler ve işletmeler üzerinde bask1 gücü oluşturmaya başlamıştır.

“Insanlığın akla gelebilecek bütün ihtiyaçlarının karşılanmasını sağlayan kaynakların tüketilmemesi, tüketme bir yana tahrip edilmemesi, bugün yeryüzünde en çok dikkat edilmesi gereken konuların başında gelmektedir. Sadece gelecek nesiller için değil, içinde yaşadığımız zaman dilimlerinde bile bu kaynakların varlı̆̆ının sürmesi, hayatımızın tek teminatıdır" (Birlik Haberleri, 1997: 29). 1980'li yılların ikinci yarısı, bu anlayışın bütün insanlık tarafından paylaşıldığı bir dönem olmuştur. Özellikle, Brundtland Raporu (Birleşmiş Milletler, 1987), olarak da bilinen "Ortak Geleceğimiz" isimli tebliğin yayınlanması, bu konudaki düşünce sistemlerini büyük ölçüde etkilemiştir. Rapor, yirminci yüzyılın başı ile sonu arasındaki farklılıklara değinmekte; etkileri yüzyıllar boyunca yerel ölçekte sınırlı olan insan faaliyetlerinin, günümüzde küresel düzeyde bütün ekosistemleri etkilediği belirtilmektedir (Kula, 1998: 150).

1983 yılında yayınlanan bu raporda yer alan "yoksulluğun ve eşitsizliğin olduğu bir dünya her zaman için ekolojik ve diğer krizlere eğilimli olacaktır" ifadesi, yeni bir kavram olan sürdürülebilir kalkınmanın, düşünce sistemlerinin içinde önemli bir yer almasını săglamıştır", (Demirkan,1997: 38).

"Sürdürülebilir kalkınma kavramı Dünya Çevre ve Kalkınma komisyonu tarafindan; gelecek nesillerin kendi ihtiyaçlarını karşılaması olarak kullanılmıştır. Dolayısıyla, sürdürülebilir çalışma denince içine hem ekonomi, hem de ekoloji girmektedir" (Prokop, 1994: 52). Sürdürülebilir kalkınma kavramının bir başka tanımı ise Ortak Geleceğimiz isimli raporda şöyle verilmektedir: "Sürdürülebilir Kalkınma; gelecek kuşakların ihtiyaçlarını karşılayabilme olanağından ödün vermeksizin bugünün ihtiyaçlarını karşılayabilecek kalkınmadır" (Demirkan, 1997: 38).

Çevre bilincinin yaygınlaşması ile yeşil hareket olarak isimlendirilen bir tüketici davranış biçimi ortaya çıkmıştır. $\mathrm{Bu}$ tüketiciler (yeşil tüketiciler) çevre konusunda hassas olup kendi etraflarındaki insanları da bilinçlendirmeyi amaç edinmişlerdir. "Yeşil tüketiciler, çevrenin korunmasında kendi etkinliklerini satın alma kararlarında göstermektedirler. Çevreye dost ürünleri tercih ederek pazar koşullarl içerisinde bu ürünleri ödüllendirmektedirler. Yeşil tüketici bir taraftan daha işlevsel ürünler isterken, bu ürünlerin çevreye verebileceğ $i$ olası zararları da bilmek istemektedir". Böylece yeşil hareket doğal olarak pazarlama ve reklam sektörünü de etkileyerek yeşil pazarlama veya çevrecilik yönelimli pazarlama kavramını doğurmuştur. "Ajanslar, reklam verenlerin istekleri sonucunda tüketicilere yeșil mesajlar vermeye başlamışlardır. Yeşil pazarlama üretimin ve tanitımın her aşamasında kendini gösterirken paketlemede özellikle yiyecek endüstrisinden başlayarak etkisini sürdürmektedir" (Odabaş1, 1992: 2-4).

Çevrecilik akımıyla ortaya çıkan bu pazarlama sistemine birçok değişik isim verilmektedir. Bunlara örnek olarak, "yeşil pazarlama", "ekolojik pazarlama" veya "çevreci pazarlama" verilebilir. Ancak aşağıda verilecek tanımlamaların temel özelliklerini incelediğimizde, bu araştırmada birden fazla isimin yaratacağı karmaşadan kurtulmak amacıyla bu pazarlama sistemine "Çevrecilik yönelimli pazarlama" adı verilmesi uygun bulunmuştur. Çevrecilik Yönelimli Pazarlamayı (ÇYP), birçok yazar ve 
bilim adamı değişik bakış açılarıyla tanımlamıştır. Bu tanımlardan bir kaçı şöyledir:

“ÇYP, geleneksel pazarlama tanımının büyük bir kısmını içine almaktadır ki, pazarlama; kişi ihtiyaç ve isteklerinin tatmin edilmesi için düşünülen her bir değişimi kolaylaştırmak ve meydana getirmek amacıla bütün faaliyetlerin düzenlenmesidir. Buradan yola çıkarak, ÇYP; organizasyonun satış amaçlarının başarılmasından, bireyler ve endüstrinin, tüketici isteklerinin tatmin edilmesine kadar olan süreçte bu sınırlı (doğal) kaynakların pazarlama faaliyetlerinde nasıl kullanıldı̆̆ını araştırmaktır" (Stanton ve Futrell, 1993: 93).

"ÇYP; doğal çevreye çok zarar veren etkilerin azaltılmastyla birlikte var olan bu ihtiyaç ve isteklerin memnuniyeti gibi insan istek ya da ihtiyaçlart için tasarlanmış her bir değişimin yapılmasını kolaylaştırmak ve bunu meydana getirmek için bütün faaliyetlerin düzenlenmesinden ibarettir” ( Polonsky, 1994: 2).

"ÇYP; kirlilik, enerji tüketimi ve enerji üretiminde kullanılmayan kaynakların tüketimi üzerinde pazarlama faaliyetlerinin pozitif ve negatif etkileri üzerinde yapılan bir çalışmadır." (Henion ve Kinnear, 1992: 3).

Görüldüğü gibi, ÇYP'nın kesin ve net bir tanımını yapmak zordur. "Pazarlama, bir ürünün yaşam döngüsünün ötesinde yeniden tüketilebilirliğini de içine alarak genişlemektedir. Üretim ile çevreci pazarlama arasındaki uyumda, kullanım, yeniden dönüşüm ve ürünün yeniden kullanımına temas edilmektedir. Pazardaki ürünler için önemli olan kullanım ve yeniden değerlenmek, yeniden stoklamak, değişiklik yapmak gibi, yeniden dönüşümün her türlüsünü geliştirmektir." (Dorweiler ve Mehenna, 1995: $6)$.

\section{2. Çevreciliğin İşletmeler Düzeyinde Önemi ve Etki Alanı}

İşletmeler kuruldukları andan itibaren kurum içinde yer alan bireylere olduğu kadar topluma karşı da sorumlulukları başlar. $\mathrm{Bu}$ nedenle özellikle büyük işletmeler toplumun beklentilerine cevap vermek amacıyla, değer ölçütlerine uygun politikalar belirleyerek faaliyetlerini sürdürürler (Çelik vd., 2016: 278). İşletmelerin sosyo- ekonomik bir varlık olduğu göz önüne alındığın da, tüketicilerin davranışlarını yönlendirebilen 'Çevre Duyarlılı̆̆ı' karşısında tepkisiz kalmaları beklenemez. Özellikle pazarlama yöneticileri çevre sorunlarına duyarlı tüketicilerle karşı karşıya gelmektedir. İşletmelerin sadece kar elde etmeye çalışan kurumlar olarak değerlendiren eski anlayış yerini sosyal sorunlara duyarlı, kaliteyi hedefleyen kurumlar olarak değerlendiren yeni bir anlayış karşısında hızla önemini kaybetmektedir. Çevre dostu ürünler üretmenin ve çevre dostu pazarlar seçmenin yanı sıra esas olarak 'Çevre Dostu' anlayışının kurum kültürüne yerleşmesi gerekir (Erbaşlar, 2012: 95).

İşletmeler, sahip oldukları sosyal sorumlulukları nedeniyle, kuruluş yeri seçimini, mamul geliştirme, çeşitlendirme kararlarına kadar, ürettikleri yeni teknolojilerde ve sistemlerde çevre korumasını göz önünde bulundurmalıdır. "Çevreyi koruduğunuz takdirde, yalnız doğa değil, işletmeniz de kazanır görüşü artık pek çok işletmede egemen olan bir düşüncedir. Işsletmenin kamuoyu önünde puan toplamasında en önemli etken olarak çevreye saygl gösterilmektedir" (Gökbunar, 1995: 4).

Çevre sorunlarının ve bunlar karşısında doğan tepkilerin işletmeleri etkilediği alanlar aşağıda ki gibidir (Erdoğan ve Ejder, 1997: 104).

Finansman Fonksiyonu Üzerindeki Etkileri: Bu etki, çevresel yatırımların ve tazminatların getireceği finansal yüktür. İşletmelerin üretim yaptıkları ülkelerin yasal olarak çevreyi koruyan yatırımları zorunlu kılması sonucu toplumdan gelen yoğun baskılar sonucunda da, mevcut teknolojisini değiştirmek zorunda kalabilecek olan işletme, çevresel yatırımları yapabilmek için ya mevcut finansal kaynakları arasında yeni bir dağılım planı yapacak, ya da yeni kaynaklar bulma çabasına girişecektir.

Üretim Yönetimi Açısından Etkileri: İşletmelerin üretimleri sonucunda iki tür atıkla karşılaşmaktayız. Bu atıkların birincisi, kullanılan hammadde atığ $1 \mathrm{ki}$ bu, işletmenin kendisi tarafından oluşturulur. İkincisi, ürünün tüketilmesi sonucunda oluşan atıktır ki, bu tüketici tarafindan oluşturulur.

Bu noktada işletmeler, ortaya çıkan atık sorununa çözüm bulmak için ya mevcut üretim teknolojilerini güncelleştirecekler, ya da atık yönetimi, geri kazanma veya kaynak azaltma yöntemlerinden birini seçeceklerdir. Atık yönetimi, işletmenin var olan atıkları hangi şekilde değerleyeceği, hangi atık türü için önlem alması gerektiği gibi geniş bir faaliyet konusunu içermektedir. Bu amaçla işletmenin bunun için yapabileceği yatırım, gelecekteki faaliyetleri için de yararlı olacaktır. Geri kazanma ise, üretimden ve tüketimden sonra ortaya çıkan atıkların, işleme ve geri kazanım tesisleri yardımıyla yeniden üretim sürecine katılmasını ifade eder. $\mathrm{Bu}$, bir ölçüde işletmenin üretim maliyetlerini minimize eder. Ancak bu yöntemler içinde en çok tavsiye edileni ise kaynak azaltmadır.

"Kaynak azaltma egemen tanımıyla, ürünleri planlama, dizayn, üretme ve kullanmada çevreye hasar verici etkenlerde nicelik seviyelerini, yüzdelerini, belli bir seviyeye indirme ve o seviyede tutmaktır. Kaynak azaltma, ideal olarak, yeniden kullanilabilecek maddeleri atma yerine yıkayı yeniden kullanma, ürünleri daha az hammadde kullanarak yapma, tehlikeli maddeleri üretimde kullanmama olană̆ sağlar" (Erdoğan ve Ejder, 1997: 106).

- Pazarlama ve Halkla İlişkiler Fonksiyonu Üzerindeki Etkileri: Çevreyi kirleten bir işletmenin tüketiciler üzerindeki olumsuz etkisini ortadan kaldırmaya çalışmak, pazarlama ve halkla ilişkiler fonksiyonunun görevidir. İşletmelerin çevre kirlenmesini önlemek için yaptığ çalışmalar, tüketicilere olumlu mesajlar olarak iletilmekte ve böylece işletmeler, rakiplerine göre bir avantaj elde ederek bu konuya duyarlı olan talebi kendi lehlerine yönlendirilebilmektedir. Ancak, işletmenin çevreye zarar veren bir yatırım yapması veya faaliyetlerinin devam etmesi, işletmeyi oldukça zor duruma sokacaktır. Bu olumsuzluktan kurtulmak için işletme, tüketicisine sahip olduğu şartları açıklamaya çalışacaktır.

- Personel Yönetimi Fonksiyonuna Etkileri: İşletmenin yarattığı çevre kirliliğinin, işletmede çalışanlar üzerindeki olumsuz etkileri sonucunda iş veriminde düşmeler gözlenmektedir. Özellikle var olan kirlilik, sağlık 
problemlerinin oluşmasına neden olabilecek boyuta ulaşıyorsa, bu durumda işletmenin yükümlülükleri daha da artmaktadır. İş veriminin düşmesi işletme için tehlikelidir. Hem parasal anlamda, hem de sosyal anlamda pek çok kayba neden olmaktadır. Bu durumu düzeltmek isteyen işletme, çalışanların verimini yükseltmek için faaliyet alanları içine çevreyi ve çevresel unsurları katmaktadır. “Kirik Patrick'e göre çevrecilik, 1990'ların büyük iş dünyası konularından birisi olacaktır. Önceden anlatılan yeşiller politikasının faydalar firmanın toplumdaki ve çalışanları üzerindeki imajı açısından büyük olacaktır"(Foreman ve Woodruffe, 1994: 135).

\section{3. Çevrecilik Yönelimli Pazarlama Stratejisi Kararlar1}

\subsection{1. Çevrecilik Yönelimli Pazarlama Stratejisi Oluşturma Süreci}

Çevrecilik yönelimli pazarlama oluşturma süreci dikkat ve özen isteyen bir çalışmadır. Bu özenin nedeni, işletmenin tüketicilerini aldatmadan ve gelecekteki kendi varlığına zarar vermeyecek bir yapının geri dönüşümsüz kuruluyor olmasıdır. Çevrecilik yönelimli pazarlama faaliyeti ile piyasaya sunduğumuz çevreci (yeşil) ürünün yalnızca bazı niteliklere sahip olması yeterli değildir. Ürünü üreten işletmenin de bu felsefeye uygun çalışma koşullarına sahip olması gereklidir. Bu yapılmadığı zaman bir süre sonra müşterilerin işletmeye karşı olan güveni ve sadakatleri yok olamaya başlayacaktır.

“Çevrecilik yönelimli pazarlama oluşturma süreci yaşanırken; yalnızca ürünün birkaç özelliği değil, aynı zamanda onu üreten işletmenin de birçok özelliğini sürece katılmalıdır. Konuya bu şekilde yaklaşan işletmeler, maliyet tasarrufu, uzun vadeli kâr, yeni pazarlara ulaşma, sosyal sorumluluğu yerine getirme gibi birçok konuda avantajlı konuma gelecektir." Çevrecilik yönelimli pazarlama süreci birbirini izleyen dört aşamadan meydana gelmektedir (Coddington, 1993: 128-130):

- Çevrecilik yönelimli pazarlama düşüncesinin şirket yönetimince kabul edilmesi: Her türlü yenilik kararının uygulanması için ilk başlangıç noktası, yenilik fikrinin kabul edilmesidir. Şirket yönetiminde yeni bir fikrin uygulanmasına karar verilmesi görevi genel olarak üst düzey yöneticilerdedir. Üst düzey yönetimince fikrin kabulünden sonra diğer kademelerde çalışanlar harekete geçmektedirler. Çevrecilik yönelimli pazarlama gibi işletmenin kültürünü ve yapısını etkileme düzeyi yüksek olan fikrin her düzeydeki çalışan ve yöneticiler tarafindan benimsenmesi önemlidir. Üst düzey yönetimin çevrecilik yönelimli pazarlamaya geçişe sıcak bakmamalarının bir takım nedenleri vardır. Bunlar genelde şu başlıklarda sinıflanmaktadır (Coddingtion, 1993: 148-150):

(i) Ürün ya da markanın özündeki albeninin azalması

(ii) Yetersiz talep

(iii) Tedarikçilerle çalışma

(iv) Araştırma ve geliştirme ve/ veya yeni araçlar geliştirme maliyeti

- Çevrecilik yönelimli pazarlamanın alt yapısını oluşturmak için kurumlarla işbirliği oluşturmak: Çevrecilik yönelimli pazarlama faaliyetinin amaçlara uygun bir şekilde yapılması için işletme, bu konuda yardım, gerekli izin ve bilgileri alabileceği bazı kurum/ kuruluşlarla diyaloga girmelidir. İşletmenin seçeceği bu kurum, kuruluşlar yapılacak çalışmaların doğru ve sağlıklı bir şekilde gerçekleşmesi açısından önemli rol oynar.

İşletmenin bu amaçla işbirliği içine girebileceği kurum/kuruluşlar şunlardır (Coddington, 1993: 162):

(i) Perakendeciler

(ii) Sivil Toplum Örgütleri

(iii) Siyasi Kurumlar

(iv) Bilimsel ve Teknik Enstitüler

(v) Eğitim Kurumları

Çevre yönetim sistemini kurmak: çevrenin bir yönetim sistemi içine alınarak gözetilmesi amacıyla bazı çalışma yöntemleri veya sistemleri geliştirmiştir. Bunlar içerisinde en çok tanınan ve genel kabul gören ISO olarak kısaltılan (International Standardization Organization) kurumunun yayınladığı Çevre Yönetim Sistemi (Environmental Management Systems) isimli kılavuz yayınıdır. Bu yayını, konuların açılımına göre ISO14000, ISO14001, ISO14002 vb. başlıklarda ilgili kesimlere ulaştırıldığını görmekteyiz. Kılavuzun temel amacı, işletmelere bir yaptırım getirmek değildir. İsteğe bağlı olarak çevreyi korumayı amaçlayan ve bunu pazarlama faaliyetlerinde uygulamayı isteyen işletmelere yol göstermektir.

- Atıkların değerlendirilmesi ve atı yönetiminin oluşturulmasl: Atıkların oluşumu ve yarattığı sorunun çözümü ülkeler bazında farklılık göstermektedir. Gelişmiş birçok ülkede toplum, sanayi ve devlet işbirliği ile atıkların değerlendirilmesi için değişik sistemler geliştirilmektedir. Atıklara yalnızca çöp mantığıyla yaklaşılmadığından, bunların ekonomik önemi değerlendirilerek yeniden faaliyete katma süreci planlanmaktadır. "Atık, ürünün yaşam döngüsü içinde üç aşama boyunca meydana gelebilmektedir. Üretim aşaması sırasında, ürünün kullanılması sırasında ve ürünün çöp olarak atılması sırasında” (Türkay, 1997: 2). Bu üç aşamadaki sorunun çözümü, toplumda var olan kesimlerin kendi üstlerine düşenleri yapması ile olacaktır. Tüketiciler konuyla ilgili bilgilendirilerek tükettikleri üründen oluşan atığ şekilde değerlendirme noktalarına ulaştırmalıdır.

\subsubsection{Hedef Pazar Belirleme}

"Çăgdaş pazarlamada belirli bir malın tek bir pazarı yoktur. Genel olarak, tek bir işletme için pazarlar çok büyüktür. Pazarl oluşturan tüketicilerin ve örgütlerin hepsinin ihtiyaç duyduklarl ve istedikleri bütün malları tek bir işletme sağlayamaz. Tüketicilerin sayısı çok ve bütün ülkeye yayılmış olabilir. Ayrıca, tüketicilerin ihtiyaçları, istekleri ya da satın alma davranışları birbirinden çok farklı olabilir" (Cemalcılar, 1994: 36). Bu nedenlerin varlığından ötürü işletmeler ürettikleri malın kime ya da kimlere satılacağına en başta karar vermelidir.

Çevrecilik yönelimli pazarlama stratejisiyle ilgili kaynakları incelediğimizde, çok değişik şekillerde pazarın bölümlendiğini görmekteyiz. Bunlar şu şekildedir:

1990 yılında The Roper Organization firması tarafindan yapılan bölümlendirmeye göre tüketiciler 5 gruba ayrılmıştır (Coddington, 1993: 80 ): 
- Pek Sadık Yeşiller (True-Blue Greens): Bunlar en hareketli ve etkili yeşil tüketicilerdir. Roper firmasına göre; bunların asıl hareketleri, çevre ile ilgili çok kuvvetli ilgileri ve birbirleriyle yaptıkları dayanışma ile gelecekte genel nüfus için yeşil harekâtın liderliğini ele almaktır.

- Paralı Yeşiller (Greenback Greens): Paralı yeşiller, çevreyle ilgili vaatlerini aslında yeşil ürün için gönüllü olarak yüksek fiyat ödeyerek göstermektedirler.

- Filiz Verenler (Sprouts): Çevre hakkındaki ilgileri ve davranış sorumlulukları orta düzeydedir. Filiz verenler kesinlikle yeşil eğilime sahip gibi görünmektedirler; ancak onlar ileri çevreci hareketleri onayladıklarını henüz açıkça göstermemektedirler.
- Şikâyetçiler (Grousers): İleri çevreci hareketin noksanlıklarını göstermek yerine, mazeretlerinin bütün çeşitlerine bir bahane bulurlar ve çevrecilerin performanslarını sürekli eleştirirler.

- Esas Kahve Rengiler (Base Brown): Çevresel problemlerin bir farklılaştırma ve yenileştirme yapmasına esas olarak inanmazlar. Onlar çevre için çaba sarf edilmesini gereksiz bulurlar."

Roper Organization aynı ayırımı ve elde ettiği tüketici gruplarını Maslow'un ihtiyaç hiyerarşisine karşılık gelecek şekilde özelliklerini Tablo 1'deki gibi sınıflandırmıştır.

Tablo 1. İhtiyaç ve Davranış Hiyerarşisi

\begin{tabular}{ll}
\hline \multicolumn{1}{c}{ Maslow ( 1954) } & \multicolumn{1}{c}{ Roper ( 1990) } \\
\hline 5- Kendini Gerçekleştirme; Kendini geliştirme ve yerine getirme & $\begin{array}{l}\text { 5- Pek Sadık Yeşiller; Düşünce liderliği eğilimi başlatmak } \\
\text { yöneticilik, profesyonellik, ileri teknikte düzenleme }\end{array}$ \\
\hline 4- Takdir Edilme İhtiyacı; Kendine saygı duymak, tanımak konumlamak & $\begin{array}{l}\text { 4- Paralı Yeşiller; Açıkgöz, girişken, ümit verici, zekâ ile ilgili } \\
\text { eylemci olmayan, meşgul yaşam stili olan }\end{array}$ \\
\hline 3- Sosyal İhtiyaçlar; Sevgi, ait olmak, kabul edilme & $\begin{array}{l}\text { 3- Filiz Verenler; Çevre yâda ekonomiye her ikisine oy } \\
\text { vermeleri kesin değildir. }\end{array}$ \\
\hline 2- Güvenlik İhtiyacı; Gizlilik, korunma, hükmetme & $\begin{array}{l}\text { 2- Şikâyetçiler; Yüksek fiyata itiraz ederler sorunlar için } \\
\text { diğerlerini suçlarlar, ilgisizlikleri için pek çok bahaneleri vardır. } \\
\text { Temel görüşleri kendilerini düşünmektir. }\end{array}$ \\
\hline 1- Fiziksel İhtiyaçlar; Yiyecek, içecek, barınma & $\begin{array}{l}\text { 1- Esas Kahverengiler; En küçük çevre faaliyeti grubudur. Daha } \\
\text { çok sosyal ve ekonomik menfaatlerden mahrum bir gruptur. }\end{array}$ \\
\hline Kaynak: Coddington (1993: 87) &
\end{tabular}

Kaynak: Coddington (1993: 87)

J.Walter Thompson ve Green Market Alert şirketlerinin ayrı ayrı yaptı̆̆ bölümleme ise kısaca şu şekildedir (Thompson, 1990: 15-17; Green Market Alert, 1990: 10):

- Yeşilden daha yeşilci (Greener than Green); Çevre için birçoğu kendilerini feda edebilirler.

- Yeşilciler (Green); Çevre ile ilgilenmektedirler, ancak bazıları kendilerini çevre için feda edebilir.

- Hafif Yeşilciler (Light Green); Çevre ile ilgilidirler ancak hiç bir kimse kendini feda etmeye istekli değildir.

- Yeşilci Olmayanlar (Un-Green); Çevre ile ilgili hiç plan yapmazlar."

"Green Market Alert firmasının ayırımı şu şekildedir:

- Hayalci Yeşilciler (Visionary Greens); Değişim paradigmasını benimsemektedirler. Yeşil bu grup için bir hayat biçimidir. Ancak alış veriş biçimleri değildir. Çevre için hareketleri tutkuyla yaparlar.

- Yeşil Olabilir (Maybe-Greens); Çevreye olan ilgilerini çok yüksek düzeyde ifade ederler, ancak bunların ilgileri düzensiz hareketlerden ibarettir.

- Sabit Fikirli Kahverengiler (Hard-core Browns); Kaygısız ya da amansız bir şekilde anti-çevrecidirler. Bunların eğitim ve gelir düzeyi düşüktür.

\section{4. Çevrecilik Yönelimli Pazarlama Karması}

Çevrecilik yönelimli pazarlama çalışmalarına başlamaya karar veren bir işletme, pazarlama karması elemanlarını da konuya uygun bir şekilde düzenlemeli ve gözden geçirmelidir. Pazarlama karması elemanlarının doğasında herhangi bir değişiklik olmamakla beraber, çevre yönetim sisteminin işletmeye getirdiği değişikliğe uygun olarak karma elemanlarının da düzenlenmesi çalışmanın sağlıklı yürümesi açısından önemlidir. Pazarlama karması elemanları, mamul, fiyat, dağıtım, tutundurma olarak ayrımlanmaktadır.

\subsubsection{Mamul Kararlart}

Mal ya da mamul nedir? Endüstri malları üreten, tüketim malları üreten veya hizmet üreten bir işletme için mal aynı anlamı taşımakta mıdır? Mala ilişkin birçok değişik tanımla karşılaşmaktayız. Ancak bu tanımların esasına baktığımızda hemen hemen birbirine benzer öğelerin mevcut olduğunu görebiliriz. Malın değişik tanımları aşağıda verilmiştir.

"Mamul, bir istek ve gereksinmeyi karşılamak üzere tüketim, kullanım, ele geçirme veya dikkate alınması için bir pazara sunulan herhangi bir şeydir. Fiziksel objeleri, hizmetleri, mekânlarl, yerleri, örgütleri ve fikirleri içerir" (Kotler, 1984: 462).

"Mamul, belirli bir ihtiyacı ve isteği doyurma özelliği bulunan ve değişime konu olan her şeydir” (Cemalcılar, 1994: 81).

"Mamul, müşterilerin algılamalarına ve beklentilerine yanıt verecek ürünün fiziksel, işlevsel, tasarımsal, estetik nitelikleri yanında hizmetler demeti ile birlikte bir bütün olarak düşünülmelidir" (Yükselen, 1994: 60).

Yukarıdaki tanımların hepsinde mal, yalnızca fiziksel bir obje olarak değil, onu kullanacak olan tüketicilerin psikolojik ve sosyal beklentilerini de içeren bir unsur olarak ele alınmıştır. Günümüzde tüketicilerin satın alma davranışlarında daha bilinçli olmaları ve bekledikleri tatmin düzeylerinin her geçen gün artması, işletmeleri mamul üretme kararlarında daha dikkatli olmaya zorlamaktadır.

Çevrecilik yönelimli pazarlama da konuya bu açıdan yaklaşmaktadır. Bu konuda yapılan çalışmalar ve değişiklikler 
mamulün fiziksel yapısını daha iyileştirmek için olsa da, asıl amaç yüksek beklentiler içerisinde olan tüketicileri tatmin etmektir. Çevre sorunlarının gün geçtikçe artması ve çözüm önerilerinin bunun tam tersine azalması veya önerilerin sonuçlarını almaya yetecek zamanın daralması tüketicileri, dolayısıyla işletmeler ve hükümetleri harekete geçirmiştir. İşletmeler mevcut yapılarını analiz ederek ihtiyaç duyulan alanlarda değişiklik yaparak bu alandaki talepleri karşılamaya çalışmaktadırlar. Çevrecilik yönelimli pazarlama düşüncesinin temelini oluşturan yeşil (çevreci) ürün geliştirme süreci birbirini takip eden evrelerden oluşmaktadır.

\subsubsection{Yeşil (Çevreci) Mamul Geliştirme Evreleri}

Literatürlerde yeşil mamul için belirgin bir tanım bulunmamaktadır. Bunun nedeni ise, yeşil mamul, çevrecilik yönelimli pazarlamanın sonucu bir başka deyişle amacı olmasıdır. Yani yeşil mamul bir amaçtan doğmuştur ve çevrecilik yönelimli pazarlama ile birlikte var olmaktadır. Ancak konunun içeriğinden yola çıkarak yeşil mamulü, çevreye karşı minimum düzeyde zarar vermeyi amaç edinen bir üretim sisteminin piyasaya sunduğu mamul olarak tanımlayabiliriz.

Yeşil mamul üretme faaliyeti çok kolay olmamaktadır. Her mamul üretme düşüncesinde var olan riskler burada da vardır. Ancak buradaki en önemli konu, işletmelerin hedef pazar olarak belirlediği tüketicilerin tatmin olmasına imkân verecek mamulün hangi aşamaları içeren bir üretim sürecinden sonra bu niteliğe sahip olacağıdır. Bunun için işletme yeni yeşil mamul geliştirme sürecinde hedef pazar, diğer kuruluş ve topluluklarla işbirliğine gitmelidir. Teknik açıdan çevreye zarar vermeyen bir mamulün üretilmesi ne kadar önemliyse, tüketiciyi tatmin edecek özelliklere sahip bir mamulü satışa sunmak da eşit düzeyde önemlidir.

"Yeşil mamul üretim fikri ilk başta zor hatta imkânsız gibi görünse de, hâlihazırda yeşil mamul başarısına sahip birçok işletme vardır. Wal-Mart, A ğustos 1989'da başlattığl yeşil etiketli özel mamul programı sonucunda 1 yıl içindeki bütün satışlarında \% 25 oranında bir artışa sahip olmuştur. Aynı şekilde ARCO-EC 1 isimli, Kuzey Kaliforniya'da faaliyet gösteren, otomobil motoru üretimi ile uğraşan firma, 1989'da başlattı̆̆ benzin emisyonu kontrolü programı sayesinde sahip olduğu pazar payında 7 ayda \% 33 den \% 35 ulaşan bir artış sağlamıştır" (Coddington, 1993: 148).

Yeşil ürün üreticileri için, tasarım sürecinin bir parçası olan çevresel özellikler en önemli ve zorlu bir görev haline gelmiştir. Çevresel özellikler, malzeme seçimi, paketleme tasarımı ve enerji kullanımı gibi kararları içerebilmektedir (Chen, 2001: 257).

Yeşil ürün politikasının kapsadığı konular, Uydacı (2011) tarafından şu şekilde sıralanmıştır: Günümüzde var olan ve hala üretilmekte olan ürünlerin, değiştirilerek veya farklılaştırılarak geliştirilmesi sonucu çevreye zararlı bir ürünün yeşil bir ürün haline dönüştürülmesi, Yeni ürünler geliştirerek yeni pazarlar yaratılması ve Yeşil ürünler üreterek işletme imajının güçlendirilmesi (Uydacı, 2011'dan aktaran: Günsan vd., 2016: 4).

Yeşil ürün geliştirme evreleri aşağıdaki gibidir (Coddington, 1993: 157-159): (i) Fırsatlar: Burada esas araştırılan, işletmenin bu sürece başlamadan önce ne gibi firsatlara sahip olduğundan öte, sürecin tamamlanmasından sonra sahip olabileceği firsatları belirlemektir.

(ii) Yapabilme Imkânı: Ar-Ge bölümü, kabul edilen alternatif mamullerin çevreye ne düzeyde etki edeceğini araştırırken, Üretim Yönetimi bölümü, mamule uygun hammadde alternatiflerinin neler olabileceğini, üretim atıklarını nasıl değerlendireceğini, bunların kirlilik açısından çevreye ne gibi etkilerde bulunabileceğini tespit eder. Finans bölümü, belirlediği alternatif finans kaynaklarının mevcut çalışma sermayesi ve borçlanma politikaları üzerindeki etkilerini analiz ederken, Pazarlama bölümü, mamulün satın alımı, kullanımı ve tüketicilerin beklentilerinin neler olabileceğini araştırmalar yardımı ile ortaya koymaya çalışacaktır.

(iii) Dizayn Etme: Yapılan araştırmalar sonucunda her bir bölümden alınan veriler bir araya getirilerek birbirleri ile uyumlaştırılır. Burada amaç Ar-Ge bölümünden başlayıp, pazarlama bölümünde sonlanan verilerin yeşil mamul üretme amacına uygun olarak düzenlenmesidir. Üretilecek yeşil mamulün çevreye minimum zarar veren nitelikte olması, tüketicilerin ve finans bölümünün beklentilerine uygun bir yapıda gelişim göstermesi amaçlanır.

(iv) Deneme Üretimi (Önceden Üretim): Bu aşamada projeler halinde belirlenen ürün pazara sunulmadan önce deneme üretimine tabi tutulur. Amaçlanan değerle ortaya çıkan gerçek durum arasındaki farklar ya da olumsuzluklar bu aşamada belirlenerek düzeltilmeye çalışılır. Kabul edilebilir sınırlar içerisinde sonuçların alınması halinde bir sonraki aşamaya geçilebilir. Burada pazarlama bölümü, ortaya çıkan deneme mamulün tüketiciler ve tedarikçiler tarafından satın alınabilme miktarını değişik araştırmalar yolu ile tespit etmeye çalışacaktır.

(v) Sunuş (Üretim) ve Satış/ Dağıtım: Pazarlama bölümü, üretim sürecinde üretilen mamulün varlığı hakkında tüketicileri bilgilendirme çalışmalarına ağırlık verir. Aynı zaman da dağıtım kanalındaki aracılar ve diğer ilgili grupları da bu aşamada bilgilendirmelidir. Satış aşamasında, ürünün satışını hızlandırmak ve belirlenen hedef pazara ulaşabilmek için tutundurma karması elemanları çevreci mamulle ilgili mesajları en uygun biçimde sunmak üzere planlanır. Aynı zamanda tüketicilere çevre sorunları ile ilgili eğitimler verilmesi de bu aşamada planlanabilir.

\subsubsection{Yeşil Mamul İçin Paketleme (Ambalajlama) Çalışmaları}

Pazarda var olan ürünlerin çoğunun ambalaj içerisinde olduğu gerçeği, birçok şirket için toplam ürünün önemli bir parçasının ürün paketleme-ambalajlama olduğunu göstermektedir. Ambalajlama çevre kirliliğinin temel kaynağı olması noktasında, yeşil pazarlama tartışmalarının odak noktasının hem ambalaj hem de ambalaj ham maddesi olduğu söylenebilir (Lampe ve Gazda, 1995'den aktaran: Günsan vd., 2016: 4).

“Geri dönüşüm ile yeniden kullanım arasında anlamlı bir fark mevcuttur. Geri dönüşüm sisteminin özünde, oluşan atıkların bileşimlerinin veya parçalarının bazı teknik işlemlerden geçirilerek yeniden biçimlendirilmesi veya ayrı bir üretim sürecinde hammadde, ara madde olarak kullanılmasıdır. Yeniden kullanımda ise, atık mamuller var olan biçimleri ile 
yeniden üretim süreci içinde yer alırlar. Yeniden kullanım özelliğine sahip paketleme ise, işletmenin sattı̆̆ mamullerin niteliğine bağlıdır. Örneğin, meyve sularl, yoğurt vb. paketler/kaplar içerisinde satılan ürünlerin depozitolu sistem ile yeniden toplanarak işletmenin üretim sürecinde olduğu gibi kullanılmasını içerir"” (Coddington 1993: 158).

Akılcı paketlemede ise, üretilen paketlerin kimyasal bileşimlerinin doğada kendiliğinden ayrışabilir niteliklere sahip olarak üretilmesi esastır. Bu konuda halen birçok ülkede bilimsel araştırmalar sürmektedir. Bu sistemin yaygınlaşması için ileri teknolojik araçların var olması ve yaygınlaşması gereklidir. "Akıllı paketleme denildiğinde ortaya çıkan bir diğer anlayış ise, ürünün ambalajının veya kabının başka kullanım şekillerine imkân verecek şekilde dizayn edilmesidir. Örneğin, Sarelle'nin bardak biçimindeki kaplarda satılması, reçel vb. yiyeceklerin dekoratif ve işlevsel kavanozlarda satılması gibi. Bu özelliği sayesinde bu ambalajlar/ kaplar doğrudan atık sistemine geçmeyerek, değişik şekillerde kullanılarak değerlendirilebilmektedir" (Odabaş1, 1992: 5).

Çevrecilik yönelimli pazarlama sisteminin amacına uygun olarak paketleme/ ambalajlama tekniğinin doğru seçilmesi önemlidir. Çünkü tüketilen mamulden daha çok atık ambalajların çevreye daha az zarar vermesini önlemek zordur.

\subsubsection{Etiketleme Kararlart}

Etiketleme konusu, üretilen yeşil mamul için ayrı bir önem taşımaktadır. "Çevre ile ilgili etiketlemenin genel amacı, ürünleri ve hizmetlerin çevreye olumlu ve olumsuz etkilerini iyi bir şekilde duyurarak ve piyasa mekanizmasinı harekete geçirerek bu ürün ve hizmetlerin çevreye olan etkilerinin iyileşmesini sağlamaktır. Bir diğer deyişle ürün ve hizmetlerin, çevre ile ilgili iddia, sembol ve bilgiler içeren etiketler taşımasının genel amacı, ürün ve hizmetlerin çevre ile ilgili yönü hakkında piyasayı bilgilendirmektir" (TS EN ISO14020, 1995: 2).

Çevreci etiketlemede ulaşılmak istenen en önemli amaç, işletmenin çevreci olduğunu değişik semboller, işaretler ve terimler yoluyla tüketicilere ve ilgili kesimlere duyurmaktadır. "Çevre etiketleri yeni bir pazarlama aracı olarak keşfedildiğinden, sayıca hızla artmaktadır. Bazı AB üyesi ülkeler kendi çevre etiketlerini geliştirmeye başlamışlardır" (Ergün, 1996: 7).

\subsubsection{Fiyat Kararlart}

"Her kıt malın bir bedeli olduğuna göre, çevrenin de bir fiyatı olmast gerekir. Ancak serbest mal sayllarak özel mülkiyete konu olmayan hava, deniz, tabii manzara gibi kaynaklara fiyat biçmek, uzun bir süre ciddi bir konu sayılmamıştır. Bundan başka, bir üretim faktörü olarak tabii kaynakların sosyal maliyeti ve faydası kendiliğinden diğer fiyatlara yansıtılmamıştır. Oysa gittikçe yaygınlaşan bir görüşe göre, fiyatlar çevre kirlenme maliyetini de içine almalıdır. Yani, her mamul mutlaka çevreye getirdiği yükü yansitacak şekilde fiyatlanmalıdır. Pazar ekonomisine dayalı ülkelerde, çevre kirlenmesini önlemenin en gerçekçi yolu şüphesiz onu fiyatlar sistemine dâhil etmek olacaktır. Çevre kirlenmesinin maliyet ve fiyatlara dâhil edildiği bir sistemde, bir yandan, mesela otomobil imalatçılarının daha az kirleten bir motor yapmaları için teşvik unsurlar sağlanırken, diğer yandan da çevre kirlenmesi yapan malların üreticilerine ve tüketicilerine maliyeti doğal olarak yükseleceğinden adaletli bir maliyet dağılımı sağlanmış olacaktır” (Bilge vd., 1985: 41).

Ancak bütün bu öngörülerine rağmen, çevrecilik yönelimli pazarlama sisteminde, çevreyi göz önüne alan fiyatlama bazı kısıtları içinde barındırmaktadır. Bu konuda karşılaşılan en önemli kısıt, işletmenin doğaya verdiği zararın maliyetinin ne kadar olacağının veya ne kadar olduğunun tespitidir. Bir işletme ilk kuruluş aşamasında çevrecilik yönelimli pazarlama sistemini benimsiyor, bunun doğrultusunda çevresel etki değerlemesi yapıyor ise, atıkların oluşturacağı tahmini zararı belirleyebilir. Aynı zamanda ileriki yıllarda çalışma sistemini çevreyi gözetme amacına uygun konumlandırıyorsa, o zaman bu hareketlerin maliyeti ve çevreye verilen maliyeti rahatlıkla belirleyebilir. Bunun sonucunda, mamul fiyatlandırmasında bu faktörü rahatlıkla kullanabilir.

Ancak bütün bu kısıtlar, işletmenin çevrecilik yönelimli pazarlama sistemini kabul etmemesine bir engel değildir. Benzer sonuçlar işletmede yapılacak en önemsiz bir değişiklikte bile ortaya çıkabilecektir. Çevrecilik yönelimli pazarlama kararı kısa vadeli bir yaklaşım değildir. Bu nedenle yapılacak değişikliklerin olumlu sonucu uzun vadede kendini gösterecektir.

"Batıda "yeşil müşteriler" dünyaya kibar davrandıklarını düşünerek ekstra fiyat ödemekten mutluluk duymaktadırlar. Tüketicinin bu yaklaşımından ötürü çevre problemlerine duyarlı üretimde bulunabilecek firmaların geleceği iyi olacaktır. Bugün ABD' de çöp, asbest, kimyasal atık toplama ve yok etme, hava kirliliğ konularında ülke çapında faaliyet gösteren firmalar oldukça başarılı bir kâr çizgisindedir" (Gökbunar, 1995: 5).

\subsubsection{Dă̆ıtım Kararları}

Pazarlama literatüründe dağıtım konusu dağıtım kanalları ve fiziksel dağıtım olarak iki kısımda incelenmektedir. "Ürünler, değişik yönlerde oluşan birçok akış ya da akıntı sonucu üreticiden tüketiciye ulaşır. Üreticiden tüketiciye dek uzanan bütün bu akışların geçtiği yollara pazarlama kanalları denir. Pazarlama kanalları, ürünlerin üreticiden tüketiciye akışını olanakl hale getirir. Ürünlerin üreticiden nihai tüketiciye veya kullanıcıya akışına katılan her bir firma veya birey, pazarlama kanalı veya dağıtım kanalı olarak tanımlanır" (Oluç, 1989: 3).

Çevrecilik yönelimli pazarlama sisteminde dağıtım konusu çevreci aracılar ve yeşil taşımacılık olarak iki başlıkta incelenmektedir (Polonsky ve Wimsatt, 1997: 356):

(i) Çevreci Aracılar: Çevreci aracılar, çevre korunması konusuna duyarlı bir şekilde yaklaşan, çevreci ürünleri satmaya hassasiyet gösteren, kendi çalışmalarında çevreye karşı sorumlulukları olduklarına inanan bir özellik sergilemektedirler. "Bu aracılar, işletmelerinin kuruluş yeri seçiminde, kendi bünyelerinden çıkan atıkların azaltılmasında ve üretici işletmeden gelebilecek işbirliği tekliflerinde itirazsız çalışmayı hedeflemektedirler. Bu nedenle mağazaları ve depoları amaca uygun bir şekilde dizayn edilmiştir. İşletmenin veya gönüllü kuruluşların çalışmalarına destek vererek tüketicileri eğitme çalışmalarına katılmada isteklidir" (Polonsky ve Wimsatt, 1997: 357). Ancak ne yazık ki işletmeler her zaman bu özelliklere sahip aracılar bulamayabilirler. Bazı aracılar çevre konusunda kendilerine düşen bir sorumluluk olduğuna inanmamaktadırlar. "Bu tür 
aracılar için üretilmiş olan çevreci mamulün fiyatının diğer mamullere göre daha yüksek olmasl, bu mamul türünü mevcut mamul karmasina katmada isteksiz klmaktadır. Çünkü bu mamullerden elde edilecek kâr daha düşük olacaktır. Ayrıca bu aracılar, söz konusu mamulü almaya istekli müşteri bulmanın güç olacă̆ına da inanmaktadırlar. Buna benzer sakıncaların çözümünün üretici işletme tarafından sağlanmas ve kendilerine destek verilmesini istemektedirler" (Polonsk ve Wimsatt, 1997: 358).

(ii) Yeşil Taşımacılık: Fiziksel dağıtım faaliyetinde yer alan ulaşım konusu burada esas alınmaktadır. "Avrupa Birliği'nin almış olduğu çevre politikası kararlarına uygun olarak taşımacılıkta, kurşunsuz benzinle çalışan ve doğaya verilen zararlı havanın minimum düzeyde çıkmasına imkân veren araçların kullanılması hemen hemen birçok ülkede yaygınlaşmıştır" (Avrupa Güncel, 1997: 25). Özellikle karayolu taşımacılığında kullanımı yaygın olan ve "yeşil motor" olarak isimlendirilen taşıtların fiziki dağıtım faaliyetlerinde kullanılması, çevrecilik yönelimli pazarlama faaliyetlerinin bir ögesi olarak kabul edilmektedir. Dünya üzerinde en yaygın şekilde kullanılan karayolu taşımacılık sistemi, hava kirliliğinin oluşumunda önemli bir faktör olarak kabul edilmektedir. Çevrecilik yönelimli pazarlama sistemini benimseyen bir işletme, bütün faaliyetlerinde, çevreyi korumayı amaç edindiğinden, fiziki dağıtım görevini yerine getirecek araçları ve işletmeleri seçerken bu özelliği her zaman göz önünde bulundurmalıdır. "Çevrecilik yönelimli pazarlama sistemini benimseyen bir işletme, hem aracllarla hem de fiziksel dă̆ıtım işini yaptı̆̆ kesimlerle ortak işbirliğine gider ve aynı zamanda onları konu hakkında bilgilendirirse, kısa bir zaman sonra bu düşünceye katılmak istemeyen kesimleri kazanabilir." (Polonsky ve Wimsatt, 1997: 367).

\subsubsection{Tutundurma Kararları}

Tutundurma şu şekillerde tanımlanmaktadır: "Tutundurma, işletme tarafindan hedef pazara gönderilen ve alıcilarla iletişim kurmak, mal ve hizmetlerle ilgili bilgi vererek, işletme yararına gerekli diğer değişiklikleri să̆lamaya yönelik mesajların iletilmesine ilişkin pazarlama çabalarıdır." (Yükselen, 1994: 147).

Günümüzün iletişim ve teknoloji çağı olduğunu kabul edersek, medya araçları ve bilişim teknolojisi yardımıyla işletmelerin bu çalışmalarını yerine getirmesi zor olmamaktadır. Televizyon, gazete, radyo, internet ve birçok diğer iletişim aracıyla işletmeler tüketicilerine ulaşarak onların satın alma davranışlarına ve tercihlerine etkide bulunmaktadırlar.

Çevre sorunları bu araçlarda her geçen gün daha yaygın haber konumuna gelmekte ve tüketicileri etkilemektedir. Çevreci hareket gruplarının konu ile ilgili hassasiyet yaratmak için bu iletişim araçlarını kullanmaları sonucunda, bir yandan işletmelerin bir yandan da çevreci hareket gruplarının yaptığı tutundurma çabaları sonuçta pazarlama ve reklam sektörünü de etkilemiştir. "Yeşil hareket, doğal olarak pazarlama ve reklam sektörünü de etkileyerek "yeşil pazarlama” kavramını doğurmuştur. Ajanslar reklam verenlerin istekleri sonucunda tüketicilere “yeşil mesaj"lar vermeye başlamışlardır" (Erkman, 1991: 14).

Çevrecilik yönelimli pazarlama sistemini benimseyen işletme tutundurma karmasını amacına uygun bir şekilde hazırlarken çok dikkatli olmalı ve etkili bir tutundurma programı hazırlamalıdır. Çünkü çevreci iddiaların reklam veya satış arttırıcı çabalarda kullanılmasında göz ardı edilmeyecek en önemli nokta, aldatıcı veya yanıltıcı nitelikte olmamasıdır. Kullandığı iddianın doğruluğunu veya iddianın hangi koşullarda gerçekleşeceğini tüketicilerine vereceği mesajda belirtmelidir. "Çevreci tutundurma, çevreci mamulle birlikte birbirine uygun olmalıdır ki, mamulün canlıliğını büyütme amaçlarını yeniden kuvvetlendirsin. Açıçca, mamul bilgisi (bilgilendirmesi) çekici, anlaml ve kullanıc motivasyonunu sürdürebilir olmalıdır. Bu tutundurmanın amaca ulaşabilmesi için en önemli kisit tüketiciye güven vermektir" (Polonsky, 1994: 9).

$\mathrm{Bu}$ amaçla $\mathrm{ABD}$ ' de faaliyet gösteren pazarlama (reklam) şirketleri kullandıkları yeşil pazarlama mesajlarını güvence altına alan aşağıda verilen birtakım kriterleri hazırlayarak yerel düzeyde kullanmaktadırlar (Polonsky, 1994: 9):

(i) Çevreci faydaların durumu açıklanmalıdır.

(ii) Çevreci karakteristiklerini açıklamalıdır.

(iii) Faydanın nasıl başarıldığını açıklamalıdır.

(iv) Karşılaştırmalı farklılıkların doğruluğunu kanıtlamalıdır.

(v) Negatif faktörleri göz önüne almayı temin etmelidir.

(vi) Yalnızca anlamlı terimleri, resimleri ve sözcükleri kullanmalıdır.

$\mathrm{Bu}$ şekilde hazırlanmış ilkeler, tüketicilere güven vererek, mesajı yayınlayan firmanın sunduğu mamulün gerçek anlamda çevreye saygılı olduğunu kabul etmesine yardımcı olmaktadır. Yeşil mamul için yapılması düşünülen reklam iki şekilde hazırlanabilmektedir.

Bunlardan ilki imaj reklamları, ikincisi de mamulü anlatan reklamlardır. Bu reklam türleri aşağıdaki gibi tanımlanabilir (Coddington, 1993: 206-208):

(i) Imaj reklamları: Stratejik olarak bu reklam çeşidi risklidir. Çünkü imaj reklamları tüketicilerde, şirketlere karşı güvensizlik oluşmasında doğrudan rol oynamaktadır. Bir şirketin çevreci imajını doğrudan reklam yapmaktan çok, dolaylı olarak reklam yaparak arttırmak genelde daha iyi olmaktadır. Eğer bir şirket bir ürünün değerini artırır ve bu gelişmeleri tüketicilerine söylerse (bilgi verirse), şirket imajını dolaylı olarak arttırmaktadır. Eğer aynı firma genel hizmet ilanı şeklindeki yayına sponsor olur ve adını küçük harflerle yazdırırsa aynı şekilde dolaylı yolla imajını arttırmaktadır. Buna örnek olarak, "Bizim yaptığımız X ürün \% 30 oranında paketlemeyi azalttığı için çevreye karşı duyarlıdır. Bizim şirketimiz bu yönde daha fazla çevreci sorumluluğa sahip olmak için çalışmaktadır” şeklindeki reklam, "X şirketi olarak biz, sizin yerinize endişeleniriz"den daha iyidir. Bu gibi yaklaşım hataları şirketin iyi niyetle vermeye çalıştığı çevreci imajı daha çok zedeleyerek, tüketicinin tepkisini çeker.

(ii) Ürünü Anlatan Reklamlar: Ürünü anlatan reklam hazırlamada çevrecilik yönelimli pazarlama için dikkat edilmesi gereken dört ilke vardır.

- Genişlilik (Etraflıca Anlatma); Çevresel problemler ve yeşil mamul arasındaki bağlantının açıklanmasıdır

- Özellik ve Açıklık; Kullanılan teknik terimler tüketiciler tarafından rahat bir şekilde anlaşılacak duruma getirilmelidir. Dil sade ve anlaşılır olmalıdır.

- Farklı Kategorilere sahip olmak; İmaj reklamı hazırlanmış ve ayrıca ürün anlatan reklamda yayınlanmak isteniyorsa, bu iki farklı reklam mesajı gerektirir. İmaj reklamı, şirketin sahip 
olduğu çevreci imajı anlatırken, ürün anlatan reklam, ürünün çevreci yanını tüketiciye aktarır. $\mathrm{Bu}$ nedenle hazırlanan reklamlar farklı kategorilerde sizi temsil etmelidir.

- Oyun İçinde Yetki Vermek (Tüketici Katılımına İzin Vermek) ; Hazırlanan çevreci mesaj, tüketiciyi oluşturulmak istenen döngünün içine katmalıdır, tüketiciye katılım isteği sağlamalı ve ona sorumluluk vermelidir.

Reklamla birlikte tutundurmada kullanılabilecek bir diğer araç da satış özendirme (tutundurma) çabalardır. "Bilindiği gibi satışı arttırıcı çabalar veya satış tutundurma, sergilere ve fuarlara katılma, eşantiyon ve kupon dă̆ıtma, vitrin düzenleme gibi çabalardan oluşmaktadır" (Tokol, 1994: 152). Çevrecilik yönelimli pazarlama faaliyetleri de satış tutundurma çabalarını kullanmaktadır. Ancak burada göz önünde bulundurmaları gereken üç temel ilke söz konusudur (Coddington, 1993: 208):

- Satış tutundurma, yeni ürünlerin çevreci niteliklerinin farkında olunmasını ve denenmesini sağlayacak şekilde yapilmalidir.

- Satış tutundurma ile çevreci sorumluluğu olan ürün, rakip ürünlere karşı daha fazla çevreci dürtülerin harekete geçmesine yardımcı olmalıdır.

- Satış tutundurma, çevreyi korumak için söz veren üreticiler üzerinde daha fazla marka bağımlılı̆̆ı yaratarak onları sözlerini yerine getirmek için zorlamalıdır.

Halkla ilişkiler faaliyeti çevrecilik yönelimli pazarlamada önemli bir rol oynamaktadır. "Halkla ilişkiler, bir kişi veya örgüte karşı halkın tavrını değerler ve bunlarla ilgili olarak halkın menfaatini de gözeterek güdülecek politikaların, gen yöntemlerin neler olabileceğini saptar; bunları uygulayıp halkın anlayışını ve benimsemesini sağlamaya çalışır" (Yükselen, 1994: 165). Çevrecilik yönelimli pazarlamada da halkla ilişkiler amaca ulaşmak ve tüketicilere şirketin çalışma fikrini benimsetmeye çalışırlar. Bunun için çevre sorunlarının oluşumu, çözüm yöntemleri ve kişilere düşen sorumlulukların neler olduğu ile ilgili konularda konferans, seminer ve paneller düzenleyerek şirket hassasiyetini halka anlatmaya çalışır. Ayrıca şirket yapılacak olan bilimsel ve teknik çalışmalara sponsorluk yaparak, bu alanda yarışmalar düzenleyerek bir katılımcı ortam yaratarak şirketle halkı (tüketicileri) kaynaştırabilir.

Bütün bu karma elemanları sonuçta çevrecilik yönelimli pazarlama stratejisini uygulayan şirketin belirlediği amaçlara ulaşmasını amaçlayan bir bakış açısıyla düzenlenmelidir. Tüketiciler aldatılmadan, onların güveni kazanılarak, şirkete ve mamule sadakat (bağlılık) duyarak satın alma davranışlarına yön verilmesi ve bu hareketin uzun vadeli olması, işletmenin ulaşmak istediği en önemli hedeftir.

\section{Dünya'dan ve Türkiye'den Çevrecilik Yönelimli Pazarlama Örnekleri}

"Çevresel sorumluluk sadece şirkete değil, hammadde üreticisi, tedarikçisi, dağıtıcısı, tüketicisi olmak üzere, değer zincirinin bütün halkalarına ait bir şeydir. Ancak en çok da marka sahibi işletmelere düşen bir sorumluluktur. Toplumun gözünde belli bir kişilik ve imaja sahip olabilen markalar, yeşil pazarlamanın en etkili temsilcileri. Markalar, doğru imaja sahip olduğunda harikalar yaratabiliyor ve bu imaj pazarlama stratejileriyle doğrudan etkileşim içerisinde. Başarılı bir yeşil pazarlamanin ticari etkisini, zincirde en belirgin hisseden halka da yine marka oluyor. Öyle ki bir yanda sayginlık bir yanda ise satış ağlarını güçlendiren markalar yaratmak bu sayede mümkün oluyor. Mesela bugün en çevreci banka dediğinizde aklınıza ilk olarak Garanti'nin gelmesi boşuna değil... Banka, -asıl iş alanı olmamasına rağmen- çevreci Bonus Kart gibi ürünler geliştirip, diğer yandan da orman yangınlarını engelleme, deniz temizliği, hayvan koruma programları gibi çok sayıda çevreci projeye destek veriyor" (Dünya gazetesi, 2018: 1-2).

Dünya genelinde ve ülkemizdeki ünlü markaların çevrecilik yönelimli bir anlayışla gerçekleştirdiği çalışmalara örnek olarak aşağıdaki uygulamalar verilebilir

Yeşil Kâğıt: 3M Firması "Greener Notes” adı altında yeni bir ürün piyasaya sunmuştur. Ürünün en önemli özelliği kâğıt temelli geri dönüşümlü malzemeden üretilmiş olmasıdır. Bu yeni post-it'ler $\% 100$ geri dönüşümlü ve içerisinde en az $\% 30$ geri dönüşümlü malzeme kullanılmış. Satın alınan her paketten çıkan kodlar bir web adresine girildiğinde $3 \mathrm{M}$ firması satın alınan bu ürün karşılığında kullanıcı adına bir ağaç dikimi gerçekleştiriyor (Yıldız, 2015).

Yeşil Selpak: Standard polietilen ambalaj malzemelerinin doğada çözünme süresi 200 ile 1000 yıl arasında değişirken, Selpak'ın doğada çözünür ambalajı 2 ila 5 yıl içinde doğada çözünme özelliğine sahip. Patentli özel bir proses ile üretilen doğada çözünür ambalaj malzemesi, toprağa karıştıktan sonra bio-bozunma süreci başliyor ve doğada tamamen kayboluyor. Türkiye'de ilk ve tek olan bu uygulama ile Selpak bio-polimer ambalajları doğada tamamen çözünüyor (Haberler.com, 2011).

HP ve Geri Dönüşüm: Global anlamda yeniden kullanılabilirlik ve geri dönüşüm alanında çalışma yapan ilk şirketlerden biri de HP. Kurum ilk olarak $1981^{\text {ee de yeniden }}$ kullanılabilir ürünler kullanmaya ve 1987 'de de geri dönüşüm uygulamaya başladı. 2007 yılına gelindiği zaman, 2006 yılına oranla \% 31'lik bir büyümeyle, yaklaşık olarak 29,500 ton ağırlığına ( 60 milyon dolar ) denk gelen 3 milyon hardware ürünü yeniden kullanmak üzere topland1... HP bugün de HP LaserJet ve mürekkep püskürtmeli baskı kartuşu iade ve geriye kazandırma programı halen devam etmektedir (Dünya Gazetesi, 2018).

Hayat Su ve Su Şişesi: Hayat su firması tarafından gerçekleştirilen çalışmada "pet" su şişelerin hem boyunları kısaldı hem de kapak kalınlıkları inceldi. Hayat Su, ambalaj malzemelerini azaltma projesi kapsamında kullandığ malzeme miktarını, şişe ağırlıklarında \%20, kapaklarda ise, $\% 30$ oranında azaltmış. Bu tasarrufla da, 5 yıl içinde 15 milyon şişeye denk bir kazanç elde etmiş. Hayat Su, kısa boyun projesi ile de, çevre koruma, karbon ayak izi ve su ayak izini azaltma konusundaki bilgileri de yarım litrelik ambalajlarına taşımış (Gürel, 2009).

General Electric Çevre ve Hayali Bir Araya Getirdi: General Electric, "ecomagination" stratejisini 2005 y1lında hayata geçirdi. Temelinde de GE müşterilerinin masraflarını azaltmalarını sağlayan ve istihdam yaratan inovatif, yaratıcı teknolojiler geliştirmek yatıyor. Ecomagination dâhilindeki ürün portfolyosunda 140 'tan fazla ürün ve çözüm dahil oldu. Bu sayede GE sera gazı emisyon oranını 2004 yılına kıyasla \%29, su kullanımı oranını ise 2010 yılına kıyasla \%13.5 oranında azalttı. GE'nin hedefi 2015 yılına kadar, Ar Ge yatırımlarını 10 milyar dolara yükseltmek (EKOIQ, 2010). 
Volvo ve Japonya Başarısı: İsveçli otomobil şirketi Volvo, 1996 yılından bu yana Japon tüketicilere otomobillerin üretim ve kullanım aşamasındaki çevresel etkileri ve her bir modelin geri dönüştürülebilme nitelikleri hakkında promosyon mesajları veriyor. Çevreye ilişkin bu hassas mesaj stratejisi sayesinde Volvo, Japonya'daki pazar payını yüzde 17 artırmış durumda. Satışları da 20 bin 500 adetten 24 bin adede ulaştı. $\mathrm{Bu}$ başarı üzerine Volvo, Avrupa, Avustralya ve Amerika pazarlarında da aynı stratejiyi uygulamaya başladı (Dünya Gazetesi, 2018).

TerraCycle'ın Upcycling ve Recycling Çalışması: Atık toplama ve geri dönüşümü mümkün olmayan tüketici ambalajlarının tekrar kullanılmasını sağlayan dünyanın lider firmalarından birisi olan TerraCycle kullanılmış ambalaj ve ürünlerin toplanması (cips paketleri, şeker ambalajları, meyva suyu paketleri, kalemler ve dış firçaları gibi) ve bu kullanılmış ürünlerin toprak altına girmesini önlemek amaciyla Amerika'da otuzun üzerinde farklı marka ile birlikte çalışmaktadır. TerraCycle şimdi de Türkiye'de oldukça yaratıcı ve çevre dostu bir proje yürütüyor. Colgate Palmolive ile yapılan ortaklık sayesinde, Türkiye'nin her ilindeki okulların kullanılmış diş macunu tüpleri, kutuları ve firçalarının TerraCycle'ın Ağız Bakımı Birliklerine gönderildiği programda, toplanan öğeler, plastik saksılardan parklardaki banklara kadar değişen ürünlere dönüştürülecek. Colgate Palmolive tarafından sponsor olunan Türkiye'nin yerel okullarını içine alan bu projede, hem çocuklar geri dönüşüm ve çevre gibi konularda bilinçlendirilmiş olacak hem de kullanılmış ağız bakımı ambalajları çöpe gitmek yerine yeniden kullanılabilir ürün haline gelecekler (Erdor, 2018: 12).

Arçelik ve Enerji Verimli Cihazların Dönüşümü Projesi: Arçelik firması Enerji ve Tabi Kaynaklar Bakanlığı, Bilim, Sanayi ve Teknoloji bakanlığı, Birleşmiş Milletler kalkınma Programı ve Küresel Çevre Fonu ile ortak gerçekleştirilen " Türkiye pazarında Enerji Verimli Cihazların Dönüşümü” projesinin ortaklarından biri. $\mathrm{Bu}$ kapsamdaki faaliyetler Arçelik firması tarafindan hem bütçe hem iletişim kanalı ile destekleniyor (Arçelik Aş, 2010).

Michelin ve Yeşil Lastik: Michelin ise hammadde seçiminden ömrü sona ermiş lastiklerin geri kazanımına kadar her aşamada çevreci üretim çalışmalarını sürdürüyor. Yakıt tüketiminin yüzde 20'sinin lastikten kaynaklandığını belirten firma bu nedenle kullanıcıları bilinçlendirerek araçlarında doğru lastiği kullanmalarına yönelik çalışmalar yapıyorlar. Michelin yuvarlanma direncini düşürerek yakıt tasarrufu sağlarken, lastiklerin çevreye olan etkilerini de en aza indiriyor. Böylece sadece üretirken değil, tüketirken de lastiğin çevreye olan etkilerini en aza indiriyor. 1992'den bu yana Michelin'in yeşil lastikleri sayesinde 34 milyon ton karbondioksitin atmosfere zarar vermesi engellenmiş. Firma ayrıca son yıllarda üretim tesislerinin de çevreci özeliklerini artırma yoluna gitti. Daha az enerji kullanarak lastik üretme politikası hedefleyen şirket, üretim verimliliği artırma yolunu seçerken çevreyi de göz önünde bulunduruyor. Çevreyi korumak için X Energy Saver Green, Energy Saver gibi birçok çevreci lastik üretiyor. Böylelikle Michelin, sadece lastik üretiminde değil, dünya genelinde kauçuk ağaçlarını korumak için de faaliyetlerde bulunuyor. Michelin reklamlarında benzin pompalarına savaş açan Bibendum lastik adam ile enerjilerin doğru kullanımı ve çevreye olan etkisini vurguluyor (Haberler.com, 2017).

\section{Sonuç ve Öneriler}

İçinde bulunduğumuz dönem itibariyle çevre sorunları ve bunların yarattığı etkiler göz ardı edilemeyecek bir durumdadır. Çevrecilik yönelimli pazarlama düşüncesinin ilk ortaya çıktığı 1990 yıllardan günümüze kadar konu gerek işletmeler gerekse tüketiciler için olmasa da olur anlayışından uzaklaşarak olmazsa olmaz anlayışına ulaşmaktadır. Dünya ve Türkiye genelinde bilinen birçok büyük ve orta ölçekli işletme bu konuda hassasiyetlerini, uygulama ve üretim çalışmalarında önemli yol kat etmişlerdir. Bugün çevreyi gözeten anlayışla üretim yapan firmaların pazarlama ve satış konusunda başarı şansları oldukça yüksektir. Çevre, yaşam kalitesi, sağlıklı yaşam gibi konularda tüketicilerde bilinç düzeyinin artması ve satın alma tercihlerinde bu hususların etkili olması işletmelerin üzerinde önemli bir baskı gücü yaratmıştır.

Tüketiciler giderek daha az kirlilik yaratan, atıkları azaltan, daha fazla geri dönüşüm sağlayan yenilenebilir kaynakların üretimde daha fazla kullanımını ve ürünlerin eko sistem içinde daha güvenli olmasını talep etmektedirler. Tüketicilerin çevrenin korunması konusunda gittikçe daha fazla bilinçlenmeleri şirket yöneticilerini ve özellikle pazarlama elemanları için daha önemsenmesi gereken husus olmaktadır. İşletmeler açısından yeşil pazarlama uygulamaları maliyetlerin düşmesini, satışların artmasını sağlarken daha az hammaddeyle daha az atık oluşacağından, kaynak kullanımında verimlilik ve finansal tasarrufa ve kazanca neden olacaktır (Erbaşlar; 2012:101).

$\mathrm{Bu}$ konudaki çalışmaların önümüzdeki yıllarda teknolojinin baş döndürücü hızı ile birleşerek çok daha etkin ve vazgeçilmez olacağını söyleyebilmek mümkün. Rekabet ve ekonomik avantaj yaratmak isteyen her sektörde çevrecilik yönelimi pazarlama çalışmaları işletmelerin ana çalışma anlayışı olacaktır. Yukarıda verilen bu örnekler bu olası sonucun göstergesi olarak kabul edilebilir. Ülkemizdeki işletmelerin sektör farkı gözetmeden çevreyi korumaya dönük çalışmaları bünyesi içerisine alması gereklidir. Bu anlayışa sahip işletme sayısının çoğalması işletmelerin rekabet başarısının yanı sıra tüketicinin tercihlerini etkileme başarısı da sağlayacaktır. Bunun sonucunda çevreyi koruma üreticinin ve tüketicinin ortak hareketi ile mümkün olabilecektir.

\section{Kaynakça}

Arçelik A.Ş. (2010). Arçelik’te Enerji Verimliliği. (Erişim Tarihi: 09.03.2018), http://www.arcelikas.com/sayfa/209/Arcelik_te_Enerji_V erimliligi

Avrupa Güncel (1997). Avrupa Birliği Çevre Komisyonu Kararları. Avrupa Komisyonu Türkiye Temsilciliği Yayınlart, Mart- Nisan, 3, 25-29.

Bilge, R., Dura, C., Fisunoğlu, M., Garipoğlu, Z., \& Uslu, O. (1985). Çevre ve Ekonomi. Ankara: Türkiye Çevre Sorunlarl Vakfi.

Birleşmiş Milletler (1987). Report of the World Commission on Environment and Development Our Common Future. United Nations.

Birlik Haberleri (1997). Önce Çevre Önce İnsan. Türk Mühendis ve Mimar Odaları Birliği Yayını, Haziran Temmuz, 24, 29-32. 
Cemalcılar, İ. (1994). Pazarlama, Kavramlar ve Kararlar. İstanbul: Beta Yayın Evi.

Chen, C. (2001). Design for the environment: A quality-based model for green product development. Management Science, 47(2), 250-263.

Coddington, W. (1993). Environmental Marketing. New York: Mcgraw- Hill.

Çelik, İ.E., Akman, Ö., Ceyhan, A., \& Akman, V. (2016) Yeşil Pazarlamada Sürdürülebilirlik Ve Dünyadan Bir Örnek: Tchibo. İçinde: International Conference on Eurasian Economies (s.278-282). (Erişim Tarihi: 06.02.2018), https://www.avekon.org/papers/1660.pdf

Çevikbaş, R. (1991). Çevre Sorunları Hava, Su, Toprak ve Canlılar Üzerindeki Etkileri. Ankara: Türkiye Tabiatını Koruma Derneği Yayını.

Demirkan, M. (1997). Çevre Sorunları Artıyor. Cumhuriyet Ekonomi, Haziran, 9/39:8.

Dorweiler, A., \& Mehenna, C. (1995). Green and Green. Journal of Education For Businnes, 2(7), 6-8.

Dünya Gazetesi (2018). Yeşil Pazarlama Altın Çağında. (Erişim Tarihi: 4.03.2018), https://www.dunya.com/ozeldosya/isim-iletisim/yesil-pazarlama-altin-caginda-haberi193926

EKOIQ (2010). Ecomagination. (Erişim Tarihi: 11.03.2018), http://ekoiq.com/2010/08/04/ecomagination/

Erbaşlar, G. (2012). Yeşil Pazarlama. Mesleki Bilimler Dergisi, 1(2), 94-101.

Erdoğan, İ., \& Ejder, N. (1997). Çevre Sorunları Nedenler ve Çözümler. Ankara: Doruk Yayımcılık.

Erdor, M. (2018). Upcyling ve Re-Cycling Yöntemleriyle Yapılan Örnek Bir Çalışma. (Erişim Tarihi: 09.03.2018), http://muraterdor.com/upcyclingve-recyclingyontemleriyle-yapilan-ornek-bir-calisma,

Ergün, Ö. (1996). Avrupa Birliğinde Ekolojik Etiketler ve Ekolojik Tekstil Ürünleri. Ankara: İGEME.

Erkman, S. (1991). Çevre Bilincinin Gelişmesi İle Marketing Yeşillendi. Medya Market, 1/3:14.

Foreman, S., \& Woodruffe, H. (1994). Çevreci Stratejilerin Uygulanması, İnsan Politikası ve Gerçek Hayata Uyarlanması. (Çev. Ali Rıza Göktuna), Verimlilik Dergisi, Haziran, 5/162: 31-43, 130-145.

Gökbunar, A. R. (1995). İşletmelerin Çevrenin Korunmasında Sosyal Sorumluluğu. Ekoloji ve Çevre Dergisi, 4/14, 2-6.

Green Market Alert (1990). Green and Consumer Behavior. Green Market Alert, 3/4, 10-11.

Gürel, E. (2009). Hayat Su Kapağı ve Şişe Boyunu Kısalttı. (Erişim Tarihi: 06.03.2018), http://www.hurriyet.com.tr/ekonomi/hayat-su-kapagi-vesise-boyunu-kisaltti-12701449

Güsan, G., Aktaş, E., \& Güvendik, Ö. (2016). Yeşil Ürün Grupları Çerçevesinde Tüketici Farkındalığı. Istanbul Journal of Social Sciences.(13), 2-16.
Haberler.com (2011). Selpak Ödül Kazand1. (Erişim Tarihi: 06.03.2018), https://www.haberler.com/selpak-odulkazandi-3011747-haberi/

Haberler.com (2017). Michelin Yeşil Lastik Konseptiyle $\mathrm{Co}^{2}$ Salınımını 45 Milyon Ton Azalttı. (Erişim Tarihi: 02.03.2018), https://www.haberler.com/michelin-yesillastik-konseptiyle-co-salinimini-45-9691615-haberi/

Henion, S., \& Kinnear, A. (1992). Environmental Marketing and Managment. New York: Norton Co.

Kışlalıŏ̆lu, M., \& Berkeş, F. (1989). Çevre ve Ekoloji, Ístanbul: Remzi Kitap Evi.

Kotler, P. (1984). Pazarlama Yönetimi Çözümleme ve Denetim. (Çev. Yaman Erdal). İstanbul: Beta Dağıtım.

Kula, E. (1998). History of Environmental Economic Thought. London: Routledge,

Lampe, M., \& Gazda, G. M. (1995). Green marketing in Europe and the United States: an evolving business and society interface. International Business Review, 4(3), 295-312.

Odabaşı, Y. (1992). Yeşil Pazarlama Kavramı ve Gelişmeler. Pazarlama Dünyası Dergisi, 2/13, 1-17.

Oluç, M. (1989). Dağıtım. Pazarlama Dünyası Dergisi, 3/13, $1-9$.

Polonsky, J. M. (1994). An Introduction to Green Marketing. New York: The Haworth Press.

Polonsky, J. M., \& Wimsatt, M. T. A. (1997). Environmental Marketing Strategies, Practice, Theory, and Research. New York: The Haworth Press.

Prokop, K. M. (1994). Yeşil Yönetim. Ankara: Türkiye Çevre Vakfi Yayını.

Stanton, A., \& Futrell, M. J. (1993). Marketing and the Ecological Crisis. New York: Harper\& Row.

Tohmpson, W. J. (1990). Green Consumer. Jwt Green Watch, $1 / 2,15-17$.

Tokol, T. (1994). Pazarlama Yönetimi. Bursa: Akademi Yayın Evi.

TSE ISO 14020 (1995). Çevre Yönetimi- Çevre İle İlgili Etiketlemenin Temel Prensipleri. Ankara: Türk Standartları Enstitüsü.

Türkay, C. (1997). Ihracatımız Açısından Ambalaj Atıklarına Iliş̧kin Türkiye - AB Düzenlemeleri. Ankara: İGEME

Uydacı, M. (2011). Yeşil Pazarlama. İstanbul: Türkmen Kitapevi.

Yıldız, D. (2015). Yeşil Pazarlama. (Erişim Tarihi: 09.03.2018), https://www.slideshare.net/DilaYldz/greenmarketingyeil-pazarlama

Yükselen, C. (1994). Temel Pazarlama Bilgileri. Ankara: Adim Yayıncılık. 